Meta

Journal des traducteurs

Translators' Journal

\title{
Kalevala through Translation: Continuity, Rewriting and Appropriation of an Epic
}

\section{Éric Plourde}

Volume 51, numéro 4, décembre 2006

La traduction des noms propres (1) et Langue, traduction et mondialisation : interactions d'hier, interactions d'aujourd'hui Language, Translation and Globalization: Interactions from Yesterday, Interactions from Today (2)

URI : https://id.erudit.org/iderudit/014343ar

DOI : https://doi.org/10.7202/014343ar

Aller au sommaire du numéro

Éditeur(s)

Les Presses de l'Université de Montréal

ISSN

0026-0452 (imprimé)

1492-1421 (numérique)

Découvrir la revue

Citer cet article

Plourde, É. (2006). Kalevala through Translation: Continuity, Rewriting and Appropriation of an Epic. Meta, 51(4), 794-805. https://doi.org/10.7202/014343ar
Résumé de l'article

Le Kalevala, l'épopée nationale des Finlandais publiée au XIX ${ }^{\mathrm{E}}$ siècle et créée par E. Lönnrot à partir de chants recueillis dans la campagne carélienne (dans le nord-ouest de la Russie), est le fruit d'un long processus de réécriture, processus qui se reflète à la fois dans l'existence de plusieurs traductions dans une même langue de l'épopée finlandaise et dans l'approche privilégiée par les traducteurs. De plus, la tendance récente montre une appropriation de l'épopée par l'utilisation d'un vocabulaire particulier, d'un style de poésie spécifique à la culture traduisante. Les versions métriques en tamoul sont structurées à la manière des anciennes épopées populaires du sud de l'Inde ; la version métrique française est aussi teintée d'archaïsme surtout lexicologique, doublé d'un recours fréquent à la néologie de la part du traducteur. 


\title{
Kalevala through Translation: Continuity, Rewriting and Appropriation of an Epic
}

\author{
ÉRIC PLOURDE \\ Université de Montréal, Montréal, Canada \\ eric.plourde.1@umontreal.ca
}

\begin{abstract}
RÉSUMÉ
Le Kalevala, l'épopée nationale des Finlandais publiée au XIX ${ }^{\mathrm{e}}$ siècle et créée par E. Lönnrot à partir de chants recueillis dans la campagne carélienne (dans le nord-ouest de la Russie), est le fruit d'un long processus de réécriture, processus qui se reflète à la fois dans l'existence de plusieurs traductions dans une même langue de l'épopée finlandaise et dans l'approche privilégiée par les traducteurs. De plus, la tendance récente montre une appropriation de l'épopée par l'utilisation d'un vocabulaire particulier, d'un style de poésie spécifique à la culture traduisante. Les versions métriques en tamoul sont structurées à la manière des anciennes épopées populaires du sud de l'Inde; la version métrique française est aussi teintée d'archaïsme surtout lexicologique, doublé d'un recours fréquent à la néologie de la part du traducteur.
\end{abstract}

\section{ABSTRACT}

The Kalevala, the national epic of the Finnish people, published in the 19th century and created by E. Lönnrot from songs collected in the Karelian countryside (Northwestern Russia), is the result of a long process of rewriting. This process has manifested itself through successive retranslations in various languages and through certain strategies favored by the epic's translators. Recent translations reflect a tendency to appropriate the epic through the use of a vocabulary and poetic style that are specific to the culture of the translator. For example, verse translations in Tamil are structured in the manner of folk epics of Southern India; while in the French verse translation the translator has made abundant use of archaisms and neologisms.

\section{MOTS-CLÉS/KEYWORDS}

Kalevala, song, Tamil, French, Finnish epic

This text is the result of preliminary research within the framework of my doctoral studies, which explores a domain at the crossroads of anthropology and translation studies. The object of the research concerns the analysis of translations in minority languages of the national Finnish epic Kalevala, written by Elias Lönnrot at the beginning of the 19th century. This analysis is an attempt to tackle issues raised by Steiner (1975: 416) on translation as a process of correcting and critiquing the original, and to explore several other questions pointed out by Ilomäki (1998) with respect to retranslations. The analysis has to do with evaluating the power relationships between languages and their relative weights, irrespective of the number of people speaking them. The analysis also considers the role and position of the translator in the process of translation, as a mode of transmitting cultural commodities through the exchange of symbolic capital, to borrow an expression from Bourdieu. Considering both the 
process behind the creation of the Kalevala and the chronology of the translations, my main arguments represent an attempt to evaluate the influence of the epic as the epicenter of a rather complex chain of rewritings and reinterpretations. This evaluation leads naturally to the questions of how the translators seem to rely on strategies similar to those Lönnrot used to breathe life into his work, and whether the translations are an expression of nationalism for some cultural minorities, as the Kalevala was for the Finns in the 19th century.

Working within the framework built on previous research on translation, ${ }^{1}$ influenced by A. Brisset's sociocritical work (1990), Clem Robyns' writings on translation and discursive identity (1994 and 1997) and Maria Tymoczko's on translations of oral tradition research, the analysis starts by taking into account previous articles on the translation of the Kalevala, most notably by H. Ilomäki (1998, Kalevala in translation), A. Lefevere (Kalevala in English), and A. van der Hoeven (Kalevala in Dutch). J. K. Helgason has done research along the same lines, but concerning the translation of the Njáls Saga.

\section{The Kalevala; an overview}

In reality, there are several "Kalevalas," for Lönnrot worked on several versions, successively incorporating new material from song collecting trips, until settling on a "final" version. As well, after Lönnrot's death, the epic was reformatted and adapted for new media (novel, cinema, CD-ROM, cartoon). The first version, Alku Kalevala (protoKalevala) was part of Lönnrot "Kalevelas," his dissertation on Väinämöinen, for which he wrote a draft of the epic: it was composed of 16 songs covering 5,052 lines. The first published final version (1835) of the Old Kalevala, or Vanha Kalevala, was completed after the second wave of song collecting; this version is the synthesis of 36 songs covering 12,078 lines. Lönnrot, however, was dissatisfied with the order of the songs, and went back to Karelia (Northwestern Russia) for further song collecting. He added material compiled by other collectors and rearranged the order of the songs, incorporating material to create the Uusi Kalevala or New Kalevala (1849), with 50 songs covering 22,795 lines. Lönnrot also developed a shortened version of the Kalevala. ${ }^{2}$ Although a fair number of scholars consider the Old Kalevala to be the best version, it is the New Kalevala that is considered to be the sole, "real" and "authentic" Kalevala, both in Finland and abroad. This is the version most often translated. The songs or runo consigned to the Finnish epic are of a specific type, the trochaic eight-syllable - so-called "Kalevala" - meter. In the oral tradition, the poems are sung by two individuals sitting side by side, sometimes accompanied by a third individual playing the kantele, a cithara-like instrument considered today to be the national instrument of Finland.

\section{Historical context of the creation of the book}

Before the publication of the Kalevala, the written Finnish language was limited mainly to the religious sphere. ${ }^{3}$ The literary languages in Finland were Greek, Latin, German and French - the latter still keeps a certain prestige - while the elite almost exclusively used Swedish.

During the first part of the 19th century, Europe was the scene of emergent nationalisms. The Finnish-speaking population of Finland, an autonomous Grand 
Duchy of Russia since 1809, was granted privileges that no other ethnic group in the Russian Empire could ever dream of claiming. During this period Romanticism was in full bloom and its Finnish version arose between the walls of the Åbo Academy (est. 1640), spearheaded by A.J. Sjögren. ${ }^{4}$

In 1831, the year of the foundation of the Suomalainen kirjallisuuden seura (SKS, Finnish literature society), Lönnrot, a country doctor, transcribed epic folk songs to create a sequel to his dissertation. He developed the idea of unifying the songs and their variants, some of them already available at the SKS archives, pertaining to one character or one element, and printing them in one single work. ${ }^{5}$

This method was applied to the unification of epic material, since a great number of variants (50 to 400 lines), ${ }^{6}$ were collected in an area stretching from Arkangeli ${ }^{7}$ in the north to Ingria (today Leningrad oblast, where St. Petersburg is located) in the south. Lönnrot added in the Kalevala laments, wedding lays, proverbs and charms, developed "apparently insignificant details into elements important to his work" (Oinas 1978: 290) and, more rarely, added his own poems. ${ }^{8}$

\section{Weaving the songs into one epic}

Even if Lönnrot was aware of the oral character of the songs he had collected and although he knew the tradition through which they were developed and transmitted (Lord 1991: 115), ${ }^{9}$ he had his very own conception of literature and poetry, in conflict with the illiterate singers' tradition. Although the dialogical - the double voice or 'echo' - aspect of the original poem has been maintained in the "Kalevala meter," all the possible paradigms that could have emerged from the numerous performances of the songs have not only been left out of the final versions of the Kalevala, but have also been eliminated through the writing process; the "deep epic universe [was] transformed into a linear text" (Tarkka 1996: 54). In fact, according to L. Honko (2002: 4), Lönnrot himself became "the sole performer of the whole tradition."

Lönnrot had cast upon his shoulders the monumental task of editing all the poetic material available to him. This implied first and foremost the choice of a language for the Kalevala, since the songs came from different sources. The Karelian language, different from standard Finnish, had been only very recently standardized, and the various dialects were sometimes quite divergent. ${ }^{10}$ Karelian shows more similarities with Savo Finnish than the Western dialects. For some, like Reinhold von Becker, Finnish had to be "rid of foreign improper elements." Certain intellectuals thought that Finnish borrowed too many words from Swedish and that the language had to be "renewed." The source of that renewal would have to come from the Finnish dialects. According to the same intellectuals, songs from Viena Karelia (and Savo), stood as the ideal corresponding to their own conceptions of language, a 'pure' and authentic language;" 'pure,' because it did not contain Swedish and Latin borrowings, ${ }^{12}$ since Viena Karelia had never really been under the influence of Sweden. When Lönnrot began to write the Kalevala, he focused on the elements he considered 'pure' and 'authentic,' or non-Christian and "pagan."

However, by working on the variants and weaving the text, he standardized the language of the poems so as to give coherence and unity to the final version, regardless of inconsistencies. As a result, the idiolects of the rune singers were unified and standardized. In this sense Elias Lönnrot became a real translator. He chose the variants 
of a given poem, selected the best elements of each variant and wove around them 'new' elements before confining them in the Kalevala. He then rearranged the components until he obtained some sort of coherent whole, according to his own conception of the oral poetry tradition, to obtain a "real epic" on a par with the works of other great nations (Lefevere 1990). Lönnrot contributed to the remodeling of the Finnish-Karelian folklore in its entirety, the final result showing what Finns of all walks of life consider a national treasure, unearthing the 'lost' richness of the language and an almost forgotten - albeit constructed - 'past.'

In that respect the Kalevala became an element of unification, around which Finland would gather its children and gain a certain pride in its past.

\section{Kalevala through translation}

The publication of the Kalevala in Finland was not sufficient to garner interest, even at home and among the intellectuals. ${ }^{13}$ The purpose for which it was written could be fulfilled only by exposing it to other nations. The interest for oral poetry was already fairly widespread in Europe, so there was potential for a foreign audience as well. With the Kalevala translated into certain European languages (Swedish, English, French, Russian, German), researchers, philologists and folklorists in the Western world could have a sample of the great talent of the ancient Finns. The impact of this dissertation, offering the proof that the Finns too had a "glorious past with heroes sung by its people," was in no way weakened through translation.

Unsurprisingly, the first translations of the Kalevala appeared a few years after publication of the Vanha Kalevala. In fact, in the year following publication, the Finnish Literature Society (Suomalaisen Kirjallisuuden Seura) was giving a 500 ruble reward to anyone translating the Kalevala into Swedish or German. ${ }^{14}$

The Finnish national poet, Runeberg, was responsible for the first drafts in Swedish, drafts that would later appear in the new capital's newspaper, the Helsingfors Morgonblad, between 1835 and 1836 (Magoun 1969: 352). But it wasn't until 1841 that appeared a second attempt in Swedish, by the Finno-Ugric language expert and Finnish nationalist Matias Aleksanteri Castrén (Pentikäinen 1989: 22). Right from the beginning, the influence of Swedish and the Swedish-speaking elite could be felt on Finnish literature's newly found reference book. The Swedish translations were very important, indeed absolutely decisive in the process of disseminating the Kalevala abroad. They were used as a springboard for the first French translations ${ }^{15}$ and, indirectly, for German translations.

A close scrutiny of the chronology of the Kalevala translations enables us to distinguish certain patterns or trends. For example, the first translations in a given language are often done in prose, even in an abridged version, that another more adventurous translator will try to 'improve' afterwards by doing an integral verse translation. This is the kind of process that was mentioned earlier (Steiner 1975: 416), with respect to a cumulative and reciprocal act of correction and critique, not unlike the numerous reinterpretations of musical compositions. These "retranslations" are also built up like a chain in which the first translations done in the 19th century and the beginning of the 20th were often augmented with a presentation of the Finnish people, in a vaguely "anthropological" manner, accentuating the "primitive" character of the Karelians. ${ }^{16}$ The next wave of translations was commonly an adaptation of the 
whole book or a specific part of the book for children, and this time the translator emphasized the fantastic nature of the tales, often using various exoticization strategies, or rather keeping only mythical elements common to both the translating and the translated culture, such as Scandinavian or Germanic themes. Another wave in the chain of retranslations may be distinguished in attempts at recasting the poetry of the original text in another light, more favorable to the "target" language or culture (Lefevere 1990).

If one takes into account the recent political changes in Europe, seen through the chronology of Kalevala translations, there is a quite interesting landscape of affirmation of cultures once obfuscated by the unilingualism or even the bilingualism of European nation-states. A glance at the chronological table (cf. Table I below) shows how visible the dismemberment of Yugoslavia appears in the translations of the Kalevala.

Politics and language go hand in hand, and one of the recent effects of globalization is closer contact between cultures that previously had few opportunities to meet directly. If during the major part of the 20th century contacts between the Communist and the Western states were conducted in the extremely tense context of the Cold War, post-1989 détente proved fruitful for some emerging states whose power had been mitigated through centralization. The history of the Kalevala in Yugoslavia can serve as an example. Yugoslavia was founded despite the fact that the Council of Croats and Slovenes desired a confederation - all members equal - while the Serbs preferred a unitary country, which meant that all the Serbian nation would be unified under one state. Such tensions within Yugoslavia, coupled with divergences of religious nature, resulted in separation, ethnic clashes and outright war in the 1990's. Taking a closer look at how and when the Kalevala was translated allows us to see how this struggle for power of the various ethnic groups would unfold. A first version of the Finnish epic in Serbo-Croatian was published before World War II, in 1935-1939. During those years, Yugoslavia (a name the country received a few years earlier, in 1931) was experiencing a dictatorship under Alexander I, who was attempting to crush Croatian nationalism. The translator of the first version was Ivan S. Shajkovich and editions of his work were subsequently printed in Helsinki, then Sarajevo (1952), then in Belgrade (1964 and 1980). The sequence of locations shows that the cultural pole transmitting the translation shifted from the translated culture to the 'peripheral' translating culture and finally to the 'central' translating culture, and did not enter into contradiction with the slowly fading decentralization policy of the Serbian majority government of the post-Second World War Yugoslavia. The cover of the Serbo-Croatian version is interesting in itself, as it transforms one of the more famous episodes of the epic, Lemminkäinen plowing the earth with his horse and trampling the vipers, into a Communist-style propaganda pamphlet cover emphasizing the 'laborer toiling for the State' theme (Arttonen and Kuusi 1985: 179). Before the 1990s, a few translators from the minority cultures of Yugoslavia translated the Kalevala. The epic appeared in the Slovenian language in 1939, under the title Iz Kalevale, translated by France Bezlaj and Märta Elmgren from the Swedish version. The second translation in Slovenian was published in 1961, done by Matej Rode from the Russian adaptation for children by Lubjarskaja. ${ }^{17}$ The existence of a strong and established Serbian oral epic tradition could be the reason why no other translation was attempted after 1939 in SerboCroatian. After the fall of the Iron Curtain in 1989-1990, translations into the various 
languages of the republics that comprised Yugoslavia followed one after the other in the wake of republic secessions, starting with Slovenian (abridged version, integral issued in 1997) by Jelka Ovaska Novak and Bogdan Novak (members of the Kalevala Society); Jelka Ovaska translated several other works of Finnish literature (A. Paasilinna, V. Linna, V. Huovinen). She first worked out a prose version of the Kalevala for school children in 1991, the same year Slovenia declared unilateral independence from Yugoslavia. Around the same period a sharp increase was noticed in translations of literary works from Finnish into Slovenian. Ovaska worked directly from Finnish, as the translator claimed she was thus "getting closer to the original meaning," as opposed to the previous translators. ${ }^{18}$ After living in Finland for seven years, Jelka Ovaska toiled on the Slovenian Kalevala for ten years, with financial help from the Finnish government. Again, we have one aspect of the emancipation of the Slovenians, not only not using the Serbo-Croatian translation as a basis for retranslation but shying away from the Russian versions and also from the new language of hegemony, English. This translation was one of several elements embedded into a vast program of cooperation and cultural exchange between the fledgling nation, Slovenia, and what would become a new member of the European Union, Finland. The Finnish government, whatever its political leanings, is aware that Finnish literature is at a serious disadvantage abroad. Grants and incentives for translation are among the strategies to counterbalance this disadvantage, since objects of cultural production are among the commodities exchanged in symbolic capital and may be considered as a manifestation of cultural "existence." The second language appearing in the recent roster of translations from former Yugoslavia is Macedonian (1998), in an adaptation done by Vesna Acevska, a poet born in Skopje, the republic's capital. Among the new independent Balkan states, Macedonia has suffered a lack of recognition such that even the official name had to be changed to Former Yugoslav Republic of Macedonia (FYROM), and, although the official declaration of secession date was September 8, 1991, the Greek government objected to the use of the name Macedonia, which it considered a Hellenic name and symbol, until 1995. Even today, although the relations between Greece and FYROM have been normalized, the use of "Macedonia" is a source of disagreement between the two neighbors. Associating the name Macedonian with the language spoken by two-thirds of the fledgling republic is still litigious. For some Bulgarian scholars, Macedonian is a dialect of the Bulgarian language (Friedman 2002: 4). For Greeks, the term used to describe the language is "Slavic." The standard dialect has been recognized as the official language since 1944, the same year the ASNOM (Assembly of National Liberation of Macedonia) was formed in the context of the anti-fascist struggle in the Southern Balkans and the foundation of the constitution and political and cultural institutions that would serve later as the basis for FYROM. Vesna Acevska did the translation of the Kalevala from a recent Russian translation, further establishing Macedonian as a viable and literary language, and underscoring the continuity of Acevska's corpus of poetic production. Acevska is already recognized outside Macedonia and has been included in foreign language anthologies of Macedonian poets. The Kalevala, for Acevska, possesses the same qualities found in Gilgamesh, the Mahabharata, the Iliad and even the Bible, binding literature and history and ensuring a continuity of ancient customs and tradition. This theme must be particularly relevant for someone born in an area with a rich history, but with a literature that was channeled through more powerful neighbor 
states; translating the Kalevala is but another way of attempting to reclaim the "lost" history.

One last reminder that Yugoslavia has been dismembered and that the major ethnic groups composing it are now more divided is a translation in a language that is symbolic of the "point of no return": this is an abridged prose translation of the Finnish epic published in Croatian, in 2000, by Stjepan A. Szabo. The translator is a professional who has already translated other Finnish works such as Sinuhe Egyptilainen, a classic of Finnish literature, from English. We see that the term Serbo-Croatian for the language used mostly by Bosnians, Croats, Montenegrins and Serbs in the former Yugoslavia is being phased out of the independent Croatian republic, and that the Croats seek more than Roman script and Catholic church as the main elements marking their regained distinct identity. Furthermore, Szabo has relied on an English translation of the Kalevala to complete his own rewriting. Instead of revisiting the Serbo-Croatian version of 1935-39, Szabo chose the tabula rasa option by reclaiming the book for his own culture, ${ }^{19}$ even though some would claim that Croatian is but "a dialect of Serbo-Croatian."

It appears that translation of a book like the Kalevala is probably a lever for minority cultures, and even for linguistic emancipation, just as the Bible during the Reformation marked the start of the emancipation of the various European languages from the so-called 'civilized' languages such as Greek and Latin.

Continuity through reterritorialization ${ }^{20}$

If the translations in minority languages were done essentially in reaction to the dominant languages and represent a defensive stance (Robyns 1994) of the minority cultures, what stance towards translation would be adopted by the cultures with a very well established literary tradition, like French or Tamil, and how would the Kalevala be translated?

\section{Kalevala in Tamil}

Translations of the Kalevala in languages of the Indian subcontinent are based on the later adaptations of the Finnish epic. Although the most important language in the area, Hindi, was used for one of the few translations (1990), it was not the first. The first translation of Lönnrot's creation into an Indian language was that into Tulu, a language spoken by about two million individuals in the states of Andhra Pradesh, Kerala, Tamil Nadu, Maharashtra, Karnataka and Meghalaya. The translator was Amrta Sõmesvara. The Tamil translation came later, in 1994, but, interestingly, the translator originated not from the Indian state of Tamil Nadu, where the majority of the Tamil speakers reside, but rather from Jaffna, in Sri Lanka, where a minority of Tamil speakers has been struggling for recognition, if not independence, from the Cinghalese-speaking majority.

The translator, Ramalingam Sivalingam, moved to Finland in 1983 as a researcher in an Asian and African Studies Department and did not only a verse translation of the Kalevala in Tamil but also a prose version in 1999. He was responsible for a project for an anthology of works by Tamil authors from the very beginnings of Tamil literature in the early centuries of the Christian eras to the most recent works. Ramalingam Sivalingam first translated the Uusi Kalevala using the periya eluttu (lit.: 'big letters') style which is the closest equivalent of oral folk epic tradition existing in 
the Tamil tradition. The recitative nature of this style is akaval, used for incantations, and closely resembles the trochaic tetrameter of the Kalevala. The translator chose to add even the formulaic expletives present in the periya eluttu. He could have translated the epic in the traditional styles of the major Indian epics Mahabharata and Ramayana, which are so prevalent in all languages of India, or even kavya epics. Rather, he chose to reactualize the periya eluttu. Ramalingam Sivalingam was working within the frame of an established tradition - a tradition harking back to 100 B.C. - and like Lönnrot attempted to impose an archaic tone according to his own vision of the literary canon, in this case the Cankam corpus, which draws from oral sources but belongs to the written tradition.

Sivalingam thus dug through traditional poems to find the equivalent for the evil spirits lempo and hiisi, replacing them with the Tamil kuuli and alakai. ${ }^{21}$ In the most straightforward manner possible, the promotional objective of the whole project was explicitly stated in Finnish professor A. Parpola's introduction to the Tamil translation; furthermore, it can be seen as a continuation in the career of the translator as developed through various projects for contributing to Tamil literature. A perfect example is Sivalingam's prose version of the Kalevala in Tamil, which, as is stated by Mr. Karthigesu Sivathamby, a Professor of Tamil at the University of Jaffna, was designed in most part for a juvenile readership, not only to bring Finnish culture to Tamil readers ${ }^{22}$ but also to offer a fresh and original take on Tamil literary tradition for the new generation.

In the book, following the presentation of the Finnish epic by Arpola, Sivalingam manages to offer a few photographic glimpses of what life in Viena Karelia could have been at the time Lönnrot visited it for his song collecting trips. Thus, the voice of Lönnrot is absent, except in the poem itself, through the translator's performance.

\section{The Kalevala in French}

The first French version was done some time after the publication of the epic (Vanha Kalevala was translated into French the same year Uusi Kalevala was published). It was an abridged version from a word-for-word Swedish and Latin translation done by a friend of Léouzon le Duc, and almost a century passed before a verse translation (by Perret 1927) saw the day.

Poet Gabriel Rebourcet completed the verse translation of the Uusi Kalevala in 1991, the year of its publication. The translation is in two volumes, with the 50 songs divided in two equal parts. A short introduction (4 pages) from the translator serves as preface before the reader is thrust headlong into Song One. The poet offers his comments on translation at the end of the second tome, on page 439. No metatextual or paratextual element of the original are translated (preface and explanations by Elias Lönnrot) as they were in Magoun's translation, for example; we have access to a synthesized vision of Finland and its literature, composed by the translator. Even though we finally see a presentation of the Finnish language (not through the filter of translation) and a brief elegy to the original (a 'texte-phare ${ }^{\text {'2 }}$ ), we quickly detect the desire of cultural appropriation through reterritorialization (Brisset 1990). Rebourcet attempted to relocate the narrative frame of the Kalevala through various strategies such as the shortening of names or the clarification of nouns. He also tried to manage a vocabulary that, according to him, "evokes realities after 1550." 
This reterritorialization is often coupled with a neutralization of some terms that could be obvious cultural markers like 'sauna' or 'kantele,' which are respectively replaced by 'étuve' and 'orgue.' Thus two really important elements of Finnish culture, on the one hand an object linked to a very precise purification ritual expressed by the only word of Finnish origin to have entered the French language, and on the other hand the Finnish national musical instrument, become, through linguistic shifts, almost banal objects.

But the seal of reterritorialization which forces me to draw an obvious parallel is the strategy of archaic vocabulary used by Rebourcet and explained by him (Rebourcet 1991-II: 444) to obtain a poetry with its unique style, a monumental task of terminology and etymology in which all the words of "[...] celte, gallo ou germanique (Celtic, Gallic or Germanic) [...]" origin are chosen "[...] de préférence à un mot de racine grecque ou latine, afin d'assurer la cohérence du lexique avec sa civilisation (instead of a word with Latin or Greek roots, so as to ensure consistency between the lexical items and its civilization of origin." Rebourcet, in his desire to reproduce the archaic (and standardizing) effect that Lönnrot tried to obtain by using Karelian and unifying the variants of the Kalevala songs, displaces the topos from Eastern Finland to Northern France, in "régions comparable [à la Finlande] dans leur culture domestique et leur climat (areas similar to Finland in domestic culture and climate).” Not only does Rebourcet expose his desire to emphasize the Nordic character of France, but, by mimetism, he works exactly like the author of the "original" by casting his nets in the murky and dispersed waters of neology for specific terms to create an almost exotic atmosphere. This work evokes the principles generally applied by the translators of the Kalevala, whether they come from a minority culture or not. In this regard, according to Even-Zohar (1990: 46), ${ }^{24}$ translation tends to set its own norms and to stand in the same position regardless of the literary polysystem; and adaptations of the Kalevala do not seem to be unaffected by this dynamic.

\section{Conclusion}

The 'original' epic is already the fruit of several layers of rewriting and reinterpretations of a tradition, an intercultural dynamic linked to a much broader process of translation as the constant rewriting and diffusion of the Kalevala. The process started by Elias Lönnrot, the first 'translator' of the Finno-Karelian oral tradition, is kept alive today in Finland and abroad.

Close inspection of the chronology of the translations of the Kalevala and the details surrounding the translators has allowed us to delve further into issues concerning the foreign texts in the translating culture. Even without analyzing the text itself, we find elements that at the very least provide a clue as to what is acceptable or 'sellable' in the literary polysystem of the translating culture. Other factors influencing the translational outcome have yet to come under closer scrutiny, such as financial incentives from the Finnish institutions for translation of the Kalevala, the question of collaboration of Finnish or Finnish-born spouses with the translators, ${ }^{25}$ or the existence of translations of Lönnrot's work in other languages of the Finno-Ugrian family. 


\section{NOTES}

1. Refer to the article published in SALSA VIII Texas Linguistic Forum (Volume 44, Number 1, 2002) University of Texas in Austin, (Austin Ritsuko Kataoka, Cassandra Moore, and Katherine Zilkha, eds.) "The Dubbing of The Simpsons: Cultural Appropriation, Discursive Manipulation and Divergencies" (pp. 114-131).

2. The Lyhyt Kalevala, published in 1860 , is the short, abridged form of the epic designed especially for younger readers. It is seldom mentioned in the Kalevala literature.

3. For example the translation of the Bible by Mikael Agrikola, who also wrote the very first Finnish texts in the 16th century.

4. Sjögren was the first scholar to collect songs in Karelia, around 1825. Although his material did not influence Lönnrot's work, it was used for the Uusi Kalevala.

5. Certainly under the influence of scholars from European countries (Germany, Denmark, etc.) discovering the vast oral repertoire available to them among the 'volk' or people, and developing a literary canon out of those sources.

6. Songs are kept short to maximize a 'dramatic effect' on the listener (Oinas 1978: 288).

7. In Russian: Arkhangel'sk.

8. According to research, the percentage of lines created by E. Lönnrot is around 5 percent.

9. Actually, A. B. Lord comments the preface of the New Kalevala, where the epic's creator describes the way the songs are transmitted in the Karelian tradition.

10. Recent research shows at least two different languages in the Karelian Autonomous Republic, Olonetsian and Ludian. The Tver Karelian, spoken in the Russian district of the same name near Moscow, also shows strong dialectal differences.

11. According to Reinhold Von Becker, Swedish-speaking intellectual, in his January 9th, 1820, article published in the Turun Wikko-Sanomat.

12. V. Ruoppila mentions in his 1967 research that the language of the Kalevala shows "relatively recent" Swedish borrowings like kuppi (cup) and tynnyri (barrel) (from A. Sauvageot, 1973: 310).

13. It took a decade for the first 500 copies of the epic to be sold out.

14. Notice that no reward is offered for a Russian translation even though at the time, Finland was an Autonomous Grand Duchy of the Russian Empire.

15. Even today most of the French translations of Finnish works of literature are from the Swedish, not the Finnish language (source: Finnish Minister of Education, 2003 Statistics).

16. In the 19th century, slavophiles Danilevsky and Hilferding believed that Finns would eventually disappear and the Kalevala could be used as ethnographic material for the Russian Empire (Vihavainen 1999).

17. That Russian version served as a basis for other translations of the Kalevala, in Belorusan and Moldavian (at the time Socialist Republics of the Soviet Union).

18. Mentioned in a private interview with the translator in April 2003.

19. This reclaiming process could also be at the source of translations of the Kalevala in the Savo dialect of Finnish.

20. An appropriation of foreign elements allowing the reader to locate the narrative frame in the translated culture is called a neutralisation or the territory, or, according to A. Brisset (1990: 68), a 'reterritorialisation.'

21. The translation was done directly from Finnish and not through an intermediate translation.

22. We are offered a brief text by Asko Parpola arguing the genetic link between Finno-Ugrian and Dravidian languages.

23. From Rebourcet (1991: 438)

24. The idea of polysystem, applied to literature, supposes interaction, intersection and superposition of several systems, sometimes antagonistic but always interdependent, functioning as a whole.

25. For instance Catalan, Low German or the most recent French translation.

\section{REFERENCES}

Álvarez, R. and M. Carmen-África Vidal (ed.) (1996): Translation, Power, Subversion, Cleveland, Multilingual Matters Ltd (Topics in Translation 8).

Anttonen, P. and M. Kuusi (1985): Kalevala lipas, Helsinki, Suomalainen Kirjallisuuden Seura.

Bassnett, S. and E. Gentzler (ed.) (2001): Contemporary Translation Theories, $2^{\text {nd }}$ edition, Clevedon, Topics in Translation, Multilingual Matters. 
Bassnett, S. and A. Lefevere (1990): Translation, history and culture, New York, Pinter.

BRisset, A. (1989): «Le travail perlocutoire de la traduction MacBeth québécois», Meta 34-2, p. $179-194$.

Brisset, A. (1990): Sociocritique de la traduction: théâtre et altérité au Québec 1968-1988, Longueuil, Le Préambule.

Brown, K. (2003): The Past in Question: Modern Macedonia and the Uncertainties of Nation, Princeton, Princeton University Press.

Dingwaney, A. and C. Maier (éd.) (1995): Between Language and Cultures: Translation and CrossCultural Texts, Pittsburgh, University of Pittsburgh Press.

Dubois, T. (1993): "From Maria to Marjatta: The Transformation of an Oral Poem in Elias Lönnrot's Kalevala" in Oral Tradition 8-2, p. 247-288

Even-Zohar, I. (1990): "Polysystem Studies," in Poetics today International Journal For Theory and Analysis of Literature and Communication 1-11.

Fernandez-Vest, M.M.J. (éd.) (1987): Kalevala et traditions orales $d u$ monde, Paris, Éditions du CNRS.

Friedman, V. A. (2002): Macdonian, Languages of the World/Materials 117, Munich, Lincom Europa.

Hatim, B. et I. Mason (1990): Discourse and the Translator; London, Longman.

Helgasson, J. K. (1999): The Rewritings of the Njals Saga: Translation, Ideology and Icelandic Sagas; Topics in Translation 16, Multilingual Matters Ltd.

Honko, L. (éd.) (1990): Religion, Myth, and Folklore in the World's Epic: The Kalevala and its Predecessors, Berlin and New York, Mouton de Gruyter.

ILомёкі, Н. (1998): Kalevala in Translation, FFN 16, p. 2-7.

Lane, A. (2004): Yugoslavia: when Ideals Collide, New York, Palgrave Macmillan.

Lотте, T. (1996): “Transformations of Epic Time and Space: Creating the World's Creation in Kalevala-metric Poetry" in Oral Tradition 11-1, p. 50-84.

Magoun, F. P. (1969): Kalevala or poems from the Kaleva District, Cambridge, Harvard University Press.

Niranjani, T. (1992): Siting Translation: History, Post-Structuralism and the Colonial Context, Berkeley, University of California Press.

Oinas, F. J. (éd.) (1978): Heroic Epic and Aaga: An Introduction and Handbook to the World's Great Folk Epic, Bloomington, Indiana University Press.

Pentikäinen, J. (1989): Kalevala Mythology (Translated and edited by Ritva Poom), Indianapolis, Indiana University Press.

Perret, J.-L. (1978): Le Kalevala: épopée populaire finlandaise, Stock, Paris.

Poulton, H. (2000): Who are the Macedonians?, Bloomington, Indiana University Press.

Rebourcet, G. (1991): Le Kalevala, Épopée des Finnois, L'aube des peuples, Gallimard.

RoByns, C. (ed.) (1994): Translation and the (Re)production of Culture, selected papers of the CERA research seminars in translation studies, 1989-1991, Leuven; CERA Chair for Translation, Communication and Cultures.

Steiner, G. (1975): After Babel: Aspects of Language and Translation, Oxford, Oxford University Press.

Venuti, L. (1992): Rethinking Translation: Discourse, Subjectivity, Ideology, London and New York Routledge.

Venuti, L. (2000): The Translation Studies Reader, London and New York, Routledge.

\section{Electronic documents}

Kalevala in Tamil <http://www.heksinki.fi/ ramaling/kalevala-tamil/>. Hi-story magazine, issue 1, June 2003 <http://hi-story.org.mk/3.htm>. 


\section{ANNEX 1}

TABLE I

\begin{tabular}{|c|c|c|}
\hline 1985 & Dutch & Maria Mies Le Nobel \\
\hline 1985 & Spanish & Joaquin fernandez and Dr. Ursula Ojanen \\
\hline 1985 & English & Keith Bosley \\
\hline 1985 & Swedish & Eli Margareta Wärnhjelm \\
\hline 1985 & Tulu & Amrta Sõmesvara \\
\hline 1986 & Slovakian & Marek Svetlik \& Jan Petr Velkoborsky \\
\hline 1986 & Italian & Gabriella Agrati \\
\hline 1986 & Vietnamese & Cao Xuân Nghiêp \\
\hline 1987,2001 & Hungarian & Imre Szente \\
\hline 1988 & Italian & Gabriella Agrati \& Maria Letizia Magini \\
\hline 1988 & American English & Eino Friberg \\
\hline 1990,1997 & Hindi & Vishnu Khare \\
\hline 1991 & Arabic & Sahban Ahmad Mroueh \\
\hline 1991 & Mari & Gen. Matukovskij \\
\hline 1991 & French & Gabriel Rebourcet \\
\hline 1991 & Slovenian & Jelka Ovaska Novak \& Bogdan Novak \\
\hline 1991 & Kiswahili & Jan Knappert \\
\hline 1991 & Vietnamese & Hoàngh Thái Anh \\
\hline 1992 & Bulgarian & Nino Nikolov \\
\hline 1992 & Greek & Maria Martzoukou \\
\hline 1993 & Faroese & Jóhannes av Skardhi \\
\hline 1994 & Catalan & Encarna Sant-Celoni i Verger \\
\hline 1994 & Danish & Hilkka \& Bengt Søndergaard \\
\hline 1994 & Tamil & Ramalingam Sivalingam (prose version 1999) \\
\hline 1994 & Vietnamese & Bùi Viêt Hoa \\
\hline 1997 & Slovenian & Jelka Ovaska Novak \& Bogdan Novak \\
\hline 1997 & Catalan & Ramon Garriga-Marquès \& Pirkko-Merja Lounavaara \\
\hline 1997 & Macedonian & Vesna Acevska \\
\hline 1998 & Polish & Jerzy Litwiniuk \\
\hline 1998 & Russian & Eino Kiuru, Armas Mishin \\
\hline 1999 & Persian & $\begin{array}{l}\text { Mercedeh Khadivar Mohseni \& Mahmood Amiryar } \\
\text { Ahmadi }\end{array}$ \\
\hline 1999 & Savo Finnish & Matti Lehmonen \\
\hline 1999 & Swedish & Lars Huldén \& Mats Huldén \\
\hline 2000 & Chinese & Zhang Hua Wen \\
\hline 2000 & Croatian & Stjepan A. Szabo \\
\hline 2000 & Low German & Herbert Strehmel \\
\hline 2001 & Oriya & Mahendra Kumar Mishra \\
\hline 2001 & Udmurt & Anatolij Uvarov \\
\hline 2003 & Veps & Nina Aceva \\
\hline
\end{tabular}

